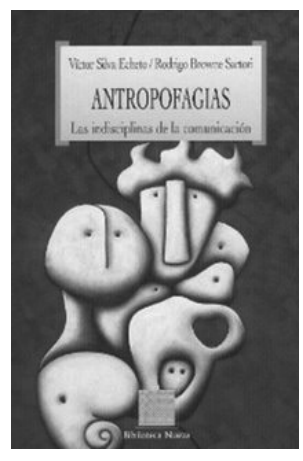

Víctor Silva Echeto y Rodrigo Browne Sartori

ANtropofagias

\title{
LAS INDISCIPLINAS DE LA COMUNICACIÓN
}

Editorial Biblioteca Nueva

Madrid, España

2007

René Jara R.

Con cierta recurrencia se abren los archivos de la discusión sobre el campo de las comunicaciones. Dentro de sus recientes aperturas, surge con periodicidad el re-planteamiento de determinados tópicos: el carácter científico de la disciplina, el objeto de estudio específico o sus propias posibilidades epistémicas de producir conocimiento. Y de qué tipo.

Esa es la discusión que desea entablar este trabajo. Quizás por eso la primera provocación, tal vez la de mayor peso, sostiene la propia presencia del libro. ¿Es posible la comunión entre el ensayo y las comunicaciones? De ser posible, ¿en qué términos es susceptible de ser planteada?

Podemos encontrar algunas respuestas en estos nueve ensayos que hacen gala de un registro escritural de trinchera, vigoroso en la defensa del género como vehículo de expresión y pensamiento. En este juego, el develamiento de la herramienta de análisis hace aparecer junto a ella la propia precariedad de los materiales utilizados. Así, la cita se utiliza frecuentemente, con cierto desparpajo y libertad.

Sin embargo, la debilidad del recurso de segunda fuente cumple, además, otro objetivo: exhibir la flaqueza de los aparatos teóricos movilizados. En razón de este argumento desfilan conceptos tales como identidad, cultura, disciplina comunicacional, multiculturalismo y postcolonialismo. Revisados y criticados, aparecen a la sazón como una especie de marcas, de simples etiquetas sobre las cuales trabaja el investigador.

Seguramente por esa razón es que la escritura se empeña en el formato de la navegación, una que parece no arribar a puerto. A la luz de los autores, interesa trabajar una mirada, un aterrizaje preciso en las voces del discurso, voces ni completas ni sesudas. Más bien fragmentarios y disolutos, nos hablan Grüner y Barbero -conocidos al dedillo-. No escasean las referencias a Canclini, a Rossana Reguillo, a Renato Ortiz o a nuestros más próximos Alicia Salomone y Grínor Rojo. 
Precisamente, estos usos que asume la escritura muestran el doble propósito: un interés por la revisión exhaustiva de la literatura especializadayuna evidente inclinaciónhaciala propuesta programática. Dentro de este punto, la idea que cobra más fuerza y que atraviesa al conjunto de ensayos es la idea del caníbal. Tratada con cierto cuidado mediante una arqueología de la palabra, donde se cruzan escrituras tan disímiles como las de Shakespeare, Fernandez Retamar y Oswaldo Andrade, alumbra un bello trabajo de búsqueda y trascendencia.

Este camino, construido en la base del intercambio con Norval Bateillo Junior en Brasil, constituye esa suerte de plataforma estéticopolítica que se levanta como una forma de pensar las indisciplinas de la comunicación: "entre la vanguardia brasileña antropófaga y la revalorización de las Américas Calibanas". La revitalización de la sugestiva idea de antropofagia cultural les sirve, por de pronto, para explicar la idea de iconofagia en la cultura occidental.

Sin ignorar el carácter dispar de algunos de los trabajos presentados en este volumen, salta a la vista el sesgo del ejercicio. Nos aproximamos a unos registros que no esconden su predilección por ciertas miradas. Por nombrar una: la enorme influencia de la llamada corriente postestructuralista encarnada en Barthes, Deleuze, Foucault y Derrida. También Imperio de Negri y Hardt, además de la inesquivable obra de Edward Said.

Se puede evidenciar, entonces, la reposición del proceso hacia el ensayo. ¿Qué se busca en esta travesía, obsesionada con el mapa, con la cartografía, con los territorios, que al mismo tiempo se dirige alegre hacia el borde del precipicio? Podemos observar con cautela el ejercicio que nos proponen Silva Echeto y Browne Sartori en estas páginas, como quien espera los frutos de una cosecha por venir. Destaquemos además la confianza, ligereza y soltura con que se aproximan ambos autores a temas de gran espesor, constituyendo un ejercicio de valiente rebeldía, frente a las cláusulas que levantan la misma academia y sus disciplinas. 